\title{
Obywatelska inicjatywa uchwałodawcza w Polsce w świetle prawa - wybrane zagadnienia
}

\begin{abstract}
Streszczenie: Obywatelska inicjatywa uchwałodawcza może być zdefiniowana jako uprawnienie mieszkańców wspólnot samorządowych do przedłożenia projektu uchwały. Wskazana forma demokracji bezpośredniej nie została wprost przewidziana przez Konstytucję RP, jak również ustawy regulujące funkcjonowanie gmin, powiatów i województw. Przedmiotowa procedura jest przyjmowana w statutach jednostek samorządu terytorialnego, co spotkało się z negatywną opinią niektórych sądów administracyjnych. Przeprowadzona analiza wskazuje jednak, iż obywatelska inicjatywa uchwałodawcza może być ustanowiona w ramach aktualnie obowiązującego porządku prawnego. W tym zakresie warto odnotować, iżtakie stanowisko zostało wyrażonem.in. w orzeczeniu Naczelnego SąduAdministracyjnegoz2013 roku.

Wydaje się, iż najlepszym rozwiązaniem byłoby ustawowe umocowanie inicjatywy uchwałodawczej mieszkańców (taka propozycja znalazła się w prezydenckim projekcie ustawy o współdziałaniu w samorządzie terytorialnym na rzecz rozwoju lokalnego i regionalnego). Przyjmując wskazane rozwiązanie, doszłoby nie tylko do rozwiania wątpliwości prawnych, lecz wystąpiłaby również szansa na upowszechnienie obywatelskiej inicjatywy uchwałodawczej. Należy pamiętać o tym, iż aktywny udział obywateli w życiu politycznym jest niezwykle istotny dla prawidłowego funkcjonowania państwa demokratycznego. W związku w tym można sformułować postulat de lege ferenda, aby przyjmowane podstawy prawne w możliwie największym stopniu umożliwiały mieszkańcom korzystanie z inicjatywy uchwałodawczej.
\end{abstract}

Słowa kluczowe: samorząd terytorialny, demokracja bezpośrednia, inicjatywa ludowa, obywatelska inicjatywa uchwałodawcza

\section{Uwagi wprowadzające}

$\mathbf{K}$ onstrukcja państwa demokratycznego zakłada aktywny udział obywateli w życiu publicznym. Formy wskazanej aktywności zmieniały się na przestrzeni wieków, co najlepiej można zobrazować porównując założenia i praktykę demokracji antycznej (bezpośredniej) i współczesnej (pośredniej). Jednakże to, co pozostaje wspólnym założeniem państw demokratycznych to udział obywateli w sprawowaniu władzy, który przybiera formę współuczestnictwa w podejmowaniu decyzji lub też może polegać na kreowaniu składu osobowego organów przedstawicielskich. W przypadku demokracji ateńskiej istota systemu politycznego sprowadzała się do odbywania regularnych spotkań obywateli celem rozstrzygania o najważniejszych sprawach wspólnoty politycznej. Taka konstrukcja była możliwa przy niedużej liczbie obywateli i niewielkim terytorium. Po wdrożeniu rozwiązań demokratycznych w państwach narodowych, które charakteryzują się większą liczbą obywateli i rozległością terytorialną, klasyczna demokracja nie miała szans na urzeczywistnienie. W związku z tym przyjęto rozwiązania polegające na wyborze przedstawicieli, którzy w imieniu suwerena podejmują najważniejsze decyzje. 
Zasadniczo rola obywateli współczesnych państw demokratycznych sprowadza się do udziału w cyklicznych i rywalizacyjnych wyborach. W ten sposób suweren kontroluje elity polityczne, które realnie sprawują władzę w państwie. Biorąc pod uwagę zasygnalizowane okoliczności możemy powiedzieć, iż współczesna demokracja to „ustrój, gdzie sprawujący władzę odpowiedzialni są na forum publicznym przed obywatelami, którzy działają za pośrednictwem obieralnych przedstawicieli, współzawodniczących i współpracujących zarazem ze sobą" (Szacka, 2008, s. 414).

Przedstawione w dużym zarysie uwagi dotyczące charakteru współczesnej demokracji odnoszą się w głównej mierze do poziomu ogólnopaństwowego. Oczywiście sprawowanie władzy na poziomie lokalnym i regionalnym również zasadniczo polega na działaniu suwerena za pośrednictwem przedstawicieli, jednakże w przypadku wspólnot lokalnych możliwości urzeczywistnienia demokracji bezpośredniej (semibezpośredniej) są zdecydowanie szersze (Musiał-Karg, 2014, s. 65). Wynika to z lepszej znajomości spraw dotyczących naszego najbliższego otoczenia, jak również niewielkiego obszaru i zazwyczaj małej liczby mieszkańców.

Celem niniejszego szkicu jest analiza podstaw prawnych jednej z form demokracji bezpośredniej występujących na poziomie lokalnym w Polsce, a mianowicie obywatelskiej inicjatywy uchwałodawczej. Wskazaną instytucję możemy zdefiniować jako uprawnienie mieszkańców wspólnoty samorządowej (gminy, powiatu, województwa) do wystąpienia z projektem uchwały. Przedmiotowa forma demokracji bezpośredniej „,należy do szerszego pojęcia inicjatywy uchwałodawczej, której krag podmiotów wyznaczają ustawy ustrojowe, inne przepisy prawne (np. ustawa o finansach publicznych) oraz akty prawa miejscowego (statuty gmin, powiatów i województw). Inicjatywą uchwałodawczą jest uprawnienie określonego, wskazanego zgodnie z przepisami prawa podmiotu do przedłożenia projektu uchwały organowi stanowiącemu (radzie gminy/powiatu lub sejmikowi województwa)" (Augustyniak, 2014, s. 364). W tym miejscu należy dodać, iż zazwyczaj w statutach ,prawo inicjatywy uchwałodawczej przyznaje się mieszkańcom gminy posiadającym prawo wybierania do rady gminy" (Brzeski, 2014, s. 383).

Obywatelska inicjatywa uchwałodawcza jest lokalnym odpowiednikiem regulacji przewidzianej przez art. 118 ust. 2 Konstytucji RP z 1997 roku, zgodnie z którym „inicjatywa ustawodawcza przysługuje również grupie co najmniej 100000 obywateli mających prawo wybierania do Sejmu. Tryb postępowania w tej sprawie określa ustawa" (Konstytucja...). Obywatelska inicjatywa ustawodawcza, podobnie jak inicjatywa uchwałodawcza przysługująca mieszkańcom jednostek samorządu terytorialnego, stanowi formę inicjatywy ludowej, którą można zdefiniować jako „uprawnienie określonej przez prawo grupy członków zbiorowego podmiotu (narodu, obywateli, ludu) do przedłożenia właściwemu organowi państwa projektu ustawy, projektu konstytucji lub do złożenia wniosku o przeprowadzenie referendum czy też o podjęcie przez organ państwowy innych działań" (Grabowska, 2005, s. 19).

Zaliczenie obywatelskiej inicjatywy uchwałodawczej do form demokracji bezpośredniej wynika z przyjęcia szerokiej definicji ostatniego ze wspomnianych terminów. Zgodnie z takim ujęciem wszelkie instytucje prawne związane ze współudziałem obywateli w procesie decyzyjnym (inicjowanie, opiniowanie, jak również zatwierdzanie) można zaliczyć do form demokracji bezpośredniej. W tym nurcie mieści się definicja zaprezentowana przez B. Banaszaka i A. Preisnera, zgodnie z którą, wspólną cechą instytucji 
demokracji bezpośredniej jest „bezpośredni udział członków zbiorowego podmiotu suwerenności w wypełnianiu przez nich funkcji publicznych" (Banaszak, Preisner, 1996, s. 152).

Początek artykułu został poświęcony na omówienie podstaw prawnych demokracji bezpośredniej na poziomie gmin, powiatów i województw. Z uwagi na przedmiot artykułu główny nacisk został położony na rozważania dotyczące obywatelskiej inicjatywy uchwałodawczej. W tym zakresie m.in. zwrócono uwagę na pojawiające się zastrzeżenia odnośnie do legalności przyjmowania omawianej formy demokracji bezpośredniej w statutach jednostek samorządu terytorialnego. Ponadto analizie poddano propozycję Prezydenta RP, aby inicjatywa uchwałodawcza mieszkańców znalazła umocowanie ustawowe. Wskazana idea została przedstawiona w prezydenckim projekcie ustawy o współdziałaniu w samorządzie terytorialnym na rzecz rozwoju lokalnego i regionalnego. Końcową część szkicu stanowi analiza rozwiązań statutowych, które określają warunki korzystania z obywatelskiej inicjatywy uchwałodawczej w Łodzi i Poznaniu.

\section{Demokracja bezpośrednia na poziomie lokalnym i regionalnym w świetle prawa}

Zgodnie z artykułem 4 Konstytucji RP z 1997 roku, ,władza zwierzchnia w Rzeczypospolitej Polskiej należy do Narodu. Naród sprawuje władzę przez swoich przedstawicieli lub bezpośrednio" (Konstytucja...). Dokonując wykładni przytoczonego przepisu należy podkreślić, iż ustawa zasadnicza podstawową rolę przypisuje demokracji przedstawicielskiej (pośredniej), co jest zgodne z wyżej poczynionymi uwagami na temat modelu współczesnej demokracji. Formy demokracji bezpośredniej mają charakter uzupełniający w stosunku do działalności przedstawicieli narodu.

Na poziomie konstytucyjnym umocowanie znalazła jedna $\mathrm{z}$ form demokracji bezpośredniej występująca na szczeblu lokalnym i regionalnym, tj. referendum. „Członkowie wspólnoty samorządowej mogą decydować, w drodze referendum, o sprawach dotyczących tej wspólnoty, w tym o odwołaniu pochodzącego z wyborów bezpośrednich organu samorząa terytorialnego. [...]" (Konstytucja ..., art. 170). W obecnym stanie prawnym zasady i tryb przeprowadzania referendum lokalnego określa ustawa z dnia 15 września 2000 roku (t.j. Dz. U. 2013, poz. 706, z późn. zm.). Pozostałe instytucje umożliwiające mieszkańcom wspólnot samorządowych bezpośrednie wykonywanie władzy są uregulowane w aktach prawnych niższego rzędu.

Ustawa z dnia 8 marca 1990 roku o samorządzie gminnym (t.j. Dz. U. 2015, poz. 1515, z późn. zm.) przewiduje (obok referendum) następujące formy demokracji bezpośredniej: konsultacje z mieszkańcami gminy (art. 5a), zebrania wiejskie (art. 36 ust. 1), ogólne zebrania mieszkańców osiedla (art. 37 ust. 4). Warto odnotować, iż obecnie na poziomie gmin intensywnie rozwija się budżet partycypacyjny, który z formalnego punktu widzenia jest formą konsultacji społecznych (zob. szerzej: Rachwał, 2013, s. 178-183; Łabędź, 2015, s. 99-100). Ustawa o samorządzie powiatowym (t.j. Dz. U. 2015, poz. 1445, z późn. $\mathrm{zm}$.) przewiduje (obok referendum) konsultacje z mieszkańcami powiatu (art. 3d). Podobnie sytuacja przedstawia się w przypadku ustawy o samorządzie województwa ${ }^{1}$. Z kolei

${ }^{1}$,W przypadkach przewidzianych ustawą oraz $\mathrm{w}$ innych sprawach ważnych dla województwa mogą być przeprowadzane na jego terytorium konsultacje z mieszkańcami województwa. Zasady i tryb 
w ustawie z dnia 15 września 2000 roku o referendum lokalnym uregulowano funkcjonowanie inicjatywy ludowej w zakresie zarządzenia referendum gminnego, powiatowego i wojewódzkiego (art. 4).

W kontekście obywatelskiej inicjatywy uchwałodawczej należy zaakcentować, iż na poziomie konstytucyjnym i ustawowym nie znajdziemy podstawy prawnej, która w sposób bezpośredni odnosiłaby się do przedmiotowej formy udziału mieszkańców w funkcjonowaniu wspólnoty samorządowej. „Nie znajduje ona [inicjatywa uchwałodawcza mieszkańców - przyp. M.R.] expressis verbis podstawy prawnej w przepisach ustaw ustrojowych" (Augustyniak, 2014, s. 363). Stosowne regulacje są przyjmowane w statutach, które „określają m.in. liczbę mieszkańców, którzy mogą wystąpić z projektem uchwały, określają procedury zgłaszania projektu" (Miruć, 2010, s. 33).

W tym miejscu należy zasygnalizować, iż można spotkać się z poglądem kwestionującym legalność wprowadzania obywatelskiej inicjatywy uchwałodawczej na podstawie statutu jednostki samorządu terytorialnego. Wskazany wniosek wypływa m.in. z wyroku Wojewódzkiego Sądu Administracyjnego we Wrocławiu z 2006 roku. „Brak w ustawie o samorządzie gminnym regulacji odnoszących się do przyznania mieszkańcom prawa do wnoszenia pod obrady rady projektów uchwał ocenić należy jako wybór ustawodawcy; jego milczenie należy interpretować w tym przypadku jako brak zgody na taką formę sprawowania władzy przez mieszkańców gminy" (Wyrok WSA we Wrocławiu...). Analogiczny wniosek wynika z orzeczenia WSA w Olsztynie z 2008 roku, który w uzasadnieniu przyjętego stanowiska zaakcentował, iż „,skoro ustawodawca zaliczył do materii ustawowej przeprowadzanie konsultacji z mieszkańcami gminy i powierzył gminie określenie ich zasad, to trudno przyjąć, aby tak ważna materia jak inicjatywa uchwałodawcza (bez wątpienia uprawnienie dalej idące niż prawo do konsultacji w ważnych sprawach gminy) i sposób jej wykonywania mogła być samoistnie uregulowana w statucie gminy" (Wyrok WSA w Olsztynie...).

Tak więc wojewódzkie sądy administracyjne we Wrocławiu i Olsztynie zakwestionowały prawo mieszkańców do obywatelskiej inicjatywy uchwałodawczej, gdyż wskazane rozwiązanie nie wynika wprost z ustawy. Dlatego też nie ma podstaw do tego, aby stosowne przepisy przyjmować w statutach gmin. W tym zakresie warto przytoczyć fragment wyroku Naczelnego Sądu Administracyjnego z dnia 8 lutego 2005 roku, w którym podkreślono, iż przyjęcie określonej kwestii w statucie jednostki samorządu terytorialnego nie wymaga wyraźnej podstawy ustawowej. „Statut może normować wszystkie zagadnienia ustrojowe gminy nie normowane wyraźnie w ustawie, byleby nie był sprzeczny z przepisami ustawowymi. Wniosek taki wynika z samorządowego charakteru gmin, które w miarę samodzielnie winny normować swą strukturę [...]. Znajduje to potwierdzenie w regulacjach Europejskiej Karty Samorządu Terytorialnego a w szczególności $\mathrm{z}$ regułą, że należy zapewnić samorządowi swobodę w kształtowaniu swych organów, jak też niezależność wybranym przedstawicielom/radnym/" (Wyrok NSA, sygn. OSK...). Jeszcze wyraźniejszy sygnał świadczący o tym, że obywatelska inicjatywa uchwałodawcza może być ustanowiona w zgodzie z obowiązującym prawem wynika $\mathrm{z}$ orzeczenia Naczelnego Sądu Administracyjnego z 2013 roku, w którym zaakcentowano, iż ,przy-

przeprowadzania konsultacji z mieszkańcami województwa określa uchwała sejmiku województwa”; ustawa z dnia 5 czerwca 1998 roku o samorzqdzie województwa, t.j. Dz. U. 2015, poz. 1392, z późn. zm., art. 10a. 
znanie grupom mieszkańców inicjatywy uchwałodawczej [...] mieści się w granicach obowiązującego prawa, a tym samym prawa tego nie narusza" (Wyrok NSA, sygn. II OSK...).

W piśmiennictwie również można odnaleźć opinie, iż ustanowienie obywatelskiej inicjatywy uchwałodawczej mieści się w obowiązującym porządku prawnym. „Stanowienie przez jednostkę samorządu terytorialnego o tym, komu przysługuje prawo inicjatywy uchwałodawczej, jest przejawem jej ustrojowej samodzielności i niezależności jako podmiotu zdecentralizowanego" (Obrzut, 2010, s. 28). W podobnym stylu wypowiedział się M. Brzeski, odnotowując iż ,generalna ustawowa klauzula delegacyjna upoważniająca organ stanowiący j.s.t. do określenia ustroju wspólnoty samorządowej w jej statucie tworzy de lege lata wystarczającą podstawę prawną regulacji obywatelskiej inicjatywy uchwałodawczej” (Brzeski, 2014, s. 400).

W omawianym zakresie swoje stanowisko wyraził także H. Izdebski, według którego „brak ustawowego uregulowania pewnej kwestii ustrojowej (milczenie ustawodawcy) nie oznacza generalnie zakazu wypowiadania się na ten temat w statucie - ograniczenie ustawą, o którym mowa w art. 169 ust. 4 Konstytucji, powinno wynikać wprost i wyraźnie z ustawy [...]. Ponieważ w odniesieniu do inicjatywy uchwałodawczej mieszkańców ustawy, w szczególności wszystkie trzy ustrojowe ustawy samorządowe, odpowiednich ograniczeń nie zawierają, wynika z tego [...] teza o dopuszczalności, lecz tylko kompleksowego, tj. bez odsyłania do odrębnych uchwał organów stanowiących, statutowego unormowania kwestii tej inicjatywy" (H. Izdebski, Podstawy...).

Podsumowując powyższe zagadnienie warto podkreślić, iż większość autorów wypowiadających się w tym zakresie dopuszcza regulację obywatelskiej inicjatywy uchwałodawczej w statucie jednostki samorządu terytorialnego. Ponadto należy mieć na uwadze stanowisko Naczelnego Sądu Administracyjnego, który w orzeczeniu z 2013 roku zaakcentował, że ustanowienie omawianej formy demokracji bezpośredniej pozostaje w zgodzie z obowiązującym prawem. W tym miejscu można sformułować uwagę ogólniejszej natury, aby interpretacja prawa dotyczącego mechanizmów partycypacji suwerena w funkcjonowaniu państwa czy wspólnoty samorządowej była możliwie przychylna obywatelom. Aktywność mieszkańców w życiu publicznym stanowi istotę demokracji i osoby odpowiedzialne za stosowanie prawa nie powinny czynić nadmiernych barier w tym zakresie.

Obywatelskie projekty uchwał są także składane w formie wniosku zgodnie z przepisami Kodeksu postępowania administracyjnego ${ }^{2}$. W nawiązaniu do takiego rozwiązania G. Makowski podkreślił, iż ,jedynie opisanie tej instytucji w statucie może zagwarantować mieszkańcom, że nie tylko będą mieli prawo do przedłożenia własnych projektów uchwał, ale także do udziału w dalszych pracach nad nimi” (G. Makowski, Czy...). Jednakże nie wszyscy autorzy wypowiadający się na temat obywatelskiej inicjatywy uchwałodawczej podzielają przedstawiony punkt widzenia. W doktrynie można spotkać

\footnotetext{
${ }^{2}$ „Organy państwowe, organy samorządu terytorialnego i inne organy samorządowe oraz organy organizacji społecznych - rozpatrują oraz załatwiają skargi i wnioski w ramach swojej właściwości” (art. 223 § 1); „Przedmiotem wniosku mogą być w szczególności sprawy ulepszenia organizacji, wzmocnienia praworządności, usprawnienia pracy i zapobiegania nadużyciom, ochrony własności, lepszego zaspokajania potrzeb ludności" (art. 241); ustawa z dnia 14 czerwca 1960 roku Kodeks postępowania administracyjnego, t.j. Dz. U. 2016, poz. 23.
} 
się z opinią, iż dyskusja w zakresie sformalizowania przedmiotowej formy demokracji bezpośredniej jest w zasadzie bezprzedmiotowa, gdyż ,czymże jest pismo chociażby jednego mieszkańca (a tym bardziej wielu mieszkańców) skierowane do rady w sprawie uchylenia wybranego przepisu bądź całej obowiązującej uchwały albo uchwalenia nowej uchwały, której projekt zostanie załączony do pisma, jeżeli nie wnioskiem (petycją) w rozumieniu k.p.a.?” (I. Krześnicki, Inicjatywa ...).

Tak więc obywatelskie projekty uchwał mogą być wnoszone na podstawie statutu jednostki samorządu terytorialnego, jak również w formie wniosku zgodnie z przepisami Kodeksu postępowania administracyjnego. W tym miejscu należy dodać, iż „istnieją jednostki samorządowe, które w swoich statutach przewidziały specjalny wariant inicjatywy uchwałodawczej przysługujący sołectwom czy osiedlom [...]. Choć możliwość przedłożenia inicjatywy uchwałodawczej może być przewidziana w statucie sołectwa [...], to jednocześnie statut samej gminy wcale nie musi zawierać specyficznych przepisów. Prawu do inicjatywy uchwałodawczej przysługującej sołectwu nie musi także towarzyszyć równolegle takie samo uprawnienie dla mieszkańców. Świadczy to o pewnym chaosie i braku standardów regulacji obywatelskiej inicjatywy uchwałodawczej w prawie miejscowym" (Makowski, 2012, s. 291). Tym samym można wyodrębnić jeszcze trzeci tryb przedkładania projektów uchwał, tj. zgodnie z regulacjami przyjętymi w statucie jednostki pomocniczej gminy.

\section{Prezydencki projekt ustawy}

W przedłożonym przez Prezydenta RP projekcie ustawy o współdziałaniu w samorządzie terytorialnym na rzecz rozwoju lokalnego i regionalnego ${ }^{3}$ została zawarta propozycja, aby do ustawy o samorządzie gminnym wprowadzić przepisy regulujące problematykę obywatelskiej inicjatywy uchwałodawczej ${ }^{4}$. Warto dodać, iż wskazana instytucja demokracji bezpośredniej miała zostać ustanowiona także na poziomie powiatu i województwa (zob. szerzej: Druk..., art. 40 pkt 8, art. 41 pkt 2). Z uwagi na ograniczone ramy artykułu w dalszej części szczegółowej analizie poddano propozycje dotyczące gmin.

„Mieszkańcom gminy mającym prawo wybierania do rady gminy przysługuje prawo obywatelskiej inicjatywy uchwałodawczej. Obywatelska inicjatywa uchwałodawcza nie może dotyczyć uchwał, dla których ustawy zastrzegają wyłączną właściwość organu wykonawczego do wniesienia projektu uchwały, w szczególności budżetu, miejscowego planu zagospodarowania przestrzennego albo ich zmian" (Druk..., art. 39 pkt 10). W ten sposób prawo do obywatelskiej inicjatywy uchwałodawczej wynikałoby wprost

\footnotetext{
${ }^{3}$ Przedmiotowy projekt uległ dyskontynuacji wraz z zakończeniem VII kadencji Sejmu RP.

${ }^{4}$ Zgodnie z projektem prezydenckim także organ uchwałodawczy jednostki pomocniczej gminy miał uzyskać ustawową gwarancję inicjatywy uchwałodawczej. Zaproponowano, aby do ustawy o samorządzie gminnym dodać art. 35a w następującym brzmieniu: „Organowi uchwałodawczemu jednostki pomocniczej przysługuje prawo inicjatywy uchwałodawczej do rady właściwej gminy. Przewodniczący rady gminy jest obowiązany wprowadzić do porządku obrad najbliższej sesji rady gminy projekt uchwały skierowany przez organ uchwałodawczy jednostki pomocniczej, jeżeli wpłynął on do rady gminy co najmniej 30 dni przed dniem rozpoczęcia sesji rady [...]"; Druk $n r$ 1699, Sejm RP VII kadencji, art. 39 pkt 28.
} 
z ustawy, co w sposób ostateczny rozwiałoby wątpliwości w zakresie legalności ustanawiania omawianej formy demokracji bezpośredniej. Warto także zwrócić uwagę, iż projekt prezydencki zawierał wyraźną podstawę prawną do ustanowienia katalogu spraw wyłączonych z obywatelskiej inicjatywy uchwałodawczej. Podobne rozwiązanie funkcjonuje w przypadku inicjatywy ustawodawczej obywateli. „Projekt ustawy nie może dotyczyć spraw, dla których Konstytucja Rzeczypospolitej Polskiej zastrzega wyłączną właściwość innych podmiotów, którym przysługuje inicjatywa ustawodawcza" (Ustawa z dnia 24 czerwca..., art. 3). W tym miejscu warto zasygnalizować, iż obywatelska inicjatywa ustawodawcza w szczególności nie może dotyczyć zmiany ustawy zasadniczej, jak również budżetu państwa (zob. szerzej: Konstytucja..., art. 221, 235; Uziębło, 2000, s. 52-53).

Omawiany projekt prezydencki przewidywał, iż zasady i tryb wykonywania obywatelskiej inicjatywy uchwałodawczej zostaną określone w statucie gminy. W szczególności miały się tam znaleźć przepisy określające:

- „minimalną liczebność grupy mieszkańców uprawnionych do głosowania w wyborach do rady gminy mogącej wystąpić z obywatelską inicjatywą uchwałodawczą, nie większą niż 15\% uprawnionych;

- tryb postępowania z projektem uchwały wniesionym jako obywatelska inicjatywa uchwałodawcza - mając na względzie jego rozpatrzenie przez radę gminy bez zbędnej zwłoki;

- uprawnienia wnioskodawców na etapie prac rady gminy nad projektem uchwały" (Druk..., art. 39 pkt 10).

Przedłożony projekt głowy państwa zawierał także w przepisach przejściowych regulacje, które miały znaleźć zastosowanie w sytuacji, gdyby organ stanowiący gminy nie znowelizował statutu, a tym samym mieszkańcy nie mogliby występować z projektami uchwał. Zgodnie z propozycją, wszelkie czynności zmierzające do zastosowania omawianej formy demokracji bezpośredniej miała wykonywać grupa inicjatywy uchwałodawczej. W jej skład miało wchodzić co najmniej 1\% uprawnionych do głosowania mieszkańców gminy (nie mniej jednak niż 100 osób). Grupa inicjatywy uchwałodawczej powinna złożyć przewodniczącemu organu stanowiącego gminy wniosek zawierający m.in. dane członków przedmiotowej grupy, wskazanie pełnomocnika i jego zastępcy, jak również projekt uchwały. Do zadań przewodniczącego organu stanowiącego zostało przypisane badanie poprawności formalnej wniosku. Jeśli w wyniku wdrożenia przedmiotowej procedury wniosek nie został odrzucony, grupa mieszkańców powinna otrzymać potwierdzenie jego przyjęcia. Wskazany moment byłby równoznaczny z uzyskaniem uprawnienia do zbierania podpisów poparcia pod projektem uchwały (wykonanie tego etapu nie powinno trwać dłużej jak 60 dni). Projekt prezydencki przewidywał zobowiązanie rady gminy do rozpatrzenia obywatelskiego projektu uchwały, jeżeli uzyskałby on poparcie co najmniej 15\% uprawnionych do głosowania mieszkańców gminy (nie mniej jednak niż 600 osób) $)^{5}$.

Przedstawiona przez Prezydenta RP propozycja ustawowego umocowania obywatelskiej inicjatywy uchwałodawczej zasługuje na pozytywną ocenę, jednakże szczegółowe

${ }^{5}$ Niniejszy akapit opracowano na podstawie przedstawionego przez Prezydenta RP projektu ustawy o współdziałaniu w samorządzie terytorialnym na rzecz rozwoju lokalnego i regionalnego oraz o zmianie niektórych ustaw; Druk $n r$ 1699..., art. 81-87. 
rozwiązania budzą pewne wątpliwości. W szczególności wskazana uwaga dotyczy ilości podpisów niezbędnych do skutecznego wystapienia z inicjatywą uchwałodawczą. Istnieje obawa, iż zaproponowany maksymalny próg poparcia, tj. 15\% uprawnionych do głosowania mieszkańców gminy zostanie przyjęty w wielu statutach (do czasu uregulowania przedmiotowej kwestii w statucie taka wysokość poparcia będzie obowiązująca we wszystkich gminach). Warto zauważyć, iż skuteczne wystapienie z inicjatywą ludową w zakresie rozpisania referendum gminnego wymaga zebrania mniejszej ilości podpisów (10\% uprawnionych do głosowania mieszkańców gminy). Odnośnie niezbędnego poparcia dla ludowej inicjatywy referendalnej istotną uwagę poczynił P. Uziębło, która tym bardziej odnosiłaby się do obywatelskiej inicjatywy uchwałodawczej. „O ile 10 proc. w niewielkich gminach stosunkowo łatwo zebrać, o tyle w największych miastach jest to już próg w zasadzie zamykający drogę inicjatywom powstałym ad hoc" (cyt. za: K. Wołodźko, Lokalni...). Tym samym można sformułować postulat de lege feren$d a$, aby liczba podpisów pod obywatelską inicjatywą uchwałodawczą została określona w sposób degresywny, tj. procentowe progi poparcia powinny maleć wraz ze wzrostem liczby mieszkańców gminy. W przeciwnej sytuacji wskazana forma demokracji bezpośredniej pozostanie incydentalnie stosowanym rozwiązaniem, co w szczególności odnosi się do większych gmin.

W rozważanym kontekście warto podkreślić, iż skuteczne wystapienie z obywatelską inicjatywą ustawodawczą jest uzależnione od zebrania co najmniej 100 tysięcy podpisów obywateli mających prawo wybierania do Sejmu. Wskazana liczba stanowi około 0,33\% ogółu wyborców. Ustanowienie 15\% progu poparcia dla skuteczności obywatelskiej inicjatywy uchwałodawczej - w przypadku największych gmin - oznaczałoby konieczność zebrania zbliżonej liczby podpisów, jak w przypadku inicjatywy ustawodawczej.

\section{Obywatelska inicjatywa uchwałodawcza na przykładzie Lodzi i Poznania}

W Łodzi z inicjatywą podjęcia uchwały może wystapić między innymi „grupa co najmniej 1000 mieszkańców Miasta Łodzi, posiadających czynne prawo wyborcze i wpisanych do stałego rejestru wyborów Miasta Łodzi” (Uchwała Nr XCIII/1964/14..., § 1). W tym miejscu warto dodać, iż do 2014 roku skuteczne złożenie obywatelskiego projektu uchwały było uzależnione od zebrania 6000 podpisów (Uchwała Nr LXVII/1301/09..., $\S 10$ ust. 2). Mieszkańcy zainteresowani złożeniem projektu uchwały składają do przewodniczącego Rady zawiadomienie zawierające (Uchwała Nr XCIII/1964/14 ..., § 1 pkt 1):

1) projekt uchwały spełniający wymogi formalne określone Regulaminem Pracy Rady Miejskiej w Łodzi;

2) listę co najmniej 15 mieszkańców Miasta Łodzi, którzy posiadają czynne prawo wyborcze i są wpisani do stałego rejestru wyborców Miasta Łodzi (grupa inicjatywna);

3) wskazanie (spośród osób tworzących grupę inicjatywną) pełnomocnika oraz jego dwóch zastępców, upoważnionych do kontaktów oraz prezentowania projektu uchwały.

Projekt uchwały jest kierowany przez przewodniczaceego Rady do Prezydenta Miasta Łodzi „w celu poddania go analizie co do zgodności z zasadami techniki prawodawczej i wydania w tym zakresie opinii w terminie 14 dni" (Ibidem). Pełnomocnik grupy 
inicjatywnej w terminie trzech miesięcy od otrzymania przedmiotowej opinii powinien przedłożyć przewodniczącemu Rady projekt uchwały wraz z listą co najmniej 1000 mieszkańców popierających obywatelski projekt uchwały. Następnie lista poparcia jest weryfikowana pod kątem zgodności z rejestrem wyborców, natomiast w odniesieniu do projektu uchwały jest wydawana opinia prawna. Przewodniczący Rady nie nadaje biegu projektowi uchwały, jeżeli wskazane czynności uwidocznią uchybienia (np. opinia prawna wykaże, że projekt uchwały jest niezgodny z prawem). Jeżeli natomiast czynności sprawdzające ,wykażą, że projektowi uchwały złożonemu przez grupę mieszkańców może być nadany bieg, przewodniczący Rady wprowadza go do porządku obrad najbliższej sesji. Jeżeli do najbliższej sesji pozostaje mniej niż 7 dni, przewodniczący Rady nadaje projektowi bieg i wprowadza go do porządku obrad kolejnej sesji” (Ibidem).

Z kolei, zgodnie ze Statutem Miasta Poznania, z inicjatywą uchwałodawczą może wystapić „każdy mieszkaniec Poznania posiadający czynne prawo wyborcze, którego wniosek poparło co najmniej 5000 innych mieszkańców Poznania posiadających czynne prawo wyborcze, w sprawach, które nie zostały ustawowo zastrzeżone do wyłącznej kompetencji Rady lub Prezydenta" (Uchwała Nr LXXX/1202/V/2010..., § 16 ust. 1 pkt 6). Tak więc obywatelska inicjatywa uchwałodawcza w Poznaniu została ograniczona do zagadnień, które nie zostały ustawowo przypisane do wyłącznej kompetencji organu stanowiącego lub wykonawczego. Każdy projekt uchwały (w tym złożony przez mieszkańców) podlega rozpatrzeniu przez Radę Miejską „,nie później niż w ciagu 3 miesięcy od daty jego złożenia" (Ibidem, § 16 ust. 2). Przytoczona regulacja nie jest oczywiście gwarancją uwzględnienia wszelkich inicjatyw uchwałodawczych, jednakże dzięki przyjęciu przedmiotowego przepisu każdy wniosek podlega rozpatrzeniu podczas sesji organu stanowiącego. W ten sposób mieszkańcy mogą zaprezentować swoją inicjatywę i zwrócić uwagę przedstawicielom na pewne problemy pozostające do rozwiązania.

Projekt uchwały składany w ramach inicjatywy ludowej powinien być „,zaopiniowany w zakresie zgodności z prawem przez radcę prawnego lub adwokata" (Ibidem, § 16 ust. 3). Tym samym na wnioskodawcach spoczywa obowiązek przedłożenia stosownej opinii. Statut Miasta Poznania reguluje także kwestię sporządzenia listy osób popierających obywatelski projekt uchwały. Stosowna lista powinna zostać przygotowana w sposób „umożliwiający stwierdzenie, że są na niej zamieszczeni wyłącznie mieszkańcy Poznania" (Ibidem). Tak więc podobnie jak w Łodzi, inicjatywa może zostać podpisana wyłącznie przez mieszkańców posiadających czynne prawo wyborcze. Na marginesie można odnotować, iż w procedurze Poznańskiego Budżetu Obywatelskiego na rok 2015 mogli uczestniczyć „,wszyscy mieszkańcy Poznania posiadający czynne prawo wyborcze, zameldowani mieszkańcy Poznania, którzy w momencie głosowania mają ukończony 16 rok życia oraz osoby studiujące w Poznaniu na podstawie numeru legitymacji studenckiej" (Zarzadzenie..., § 3). Tak więc w tym przypadku krąg uprawnionych został poszerzony poprzez obniżenie cenzusu wieku, jak również uwzględnienie osób studiujących w Poznaniu.

Zaangażowanie mieszkańców w funkcjonowanie wspólnoty samorządowej (podobnie jak w przypadku państwa) zależy między innymi od konstrukcji prawnej mechanizmów partycypacji społecznej. Zatrzymując się na obywatelskiej inicjatywie uchwałodawczej należy wskazać, iż praktyka stosowania przedmiotowej instytucji w dużym stopniu jest uzależniona od wymaganej liczby podpisów. W przypadku Poznania należy 
zebrać 5000 podpisów mieszkańców posiadających czynne prawo wyborcze, natomiast w Łodzi jest to 1000 podpisów. Próbując dokonać oceny przyjętych rozwiązań najlepiej odnieść wskazane wymogi do ogólnej liczby mieszkańców mogących poprzeć projekt uchwały. Z tak przeprowadzonej analizy wynika, iż w przypadku Poznania trzeba zebrać podpisy niespełna 1,2\% mieszkańców posiadających czynne prawo wyborcze, natomiast w Łodzi jest to nieco ponad $0,17 \%$ spośród uprawnionych do złożenia podpisu ${ }^{6}$. Tym samym wymogi stawiane mieszkańcom Poznania są dość restrykcyjne i urealnienie omawianej formy demokracji bezpośredniej byłoby możliwe w przypadku obniżenia wymaganego poparcia społecznego ${ }^{7}$.

\section{Podsumowanie}

Obywatelska inicjatywa uchwałodawcza nie jest powszechnie stosowanym mechanizmem udziału mieszkańców w funkcjonowaniu wspólnoty samorządowej. „Tam, gdzie odpowiednie uregulowania istnieja, w skali roku mieszkańcy przedkładają co najwyżej kilka projektów uchwał. Jeszcze mniej z nich jest przyjmowanych przez władze samorządowe" (Makowski, 2013, s. 19). Jak wynika z badań przeprowadzonych przez Fundację Centrum Inicjatyw na Rzecz Społeczeństwa, „niespełna jedna trzecia powiatów oraz gmin miejskich daje mieszkańcom możliwość wystapienia z inicjatywą uchwałodawczą" .

Anna Olech z Instytutu Spraw Publicznych zwróciła uwagę na dwie przeszkody w zakresie upowszechnienia obywatelskiej inicjatywy uchwałodawczej. „Pierwsza to niesprzyjające prawo: niejasność przepisów powoduje, że podważana bywa sama możliwość [uregulowania - przyp. M.R.] tej kwestii w statutach jednostek samorządu terytorialnego. Druga to niechętny stosunek władz samorządowych - mieszkańcy postrzegani są często jako nieaktywni oraz pozbawieni kompetencji do tego, aby podejmować decyzje publiczne lub choćby uruchamiać proces uchwałodawczy" (cyt. za: A. Kubel-Grabau, Mieszkańcy...). Przytoczony komentarz bardzo trafnie obrazuje istotę problemów związanych z funkcjonowaniem obywatelskiej inicjatywy uchwałodawczej. $\mathrm{Z}$ uwagi na przedmiot artykułu należy wskazać na pojawiające się wątpliwości prawne

${ }^{6}$ Obliczenia własne na podstawie danych Państwowej Komisji Wyborczej o liczbie uprawnionych do głosowania w wyborach samorządowych z 2014 roku; Państwowa Komisja Wyborcza, Wybory samorzqdowe 2014, wybory2014.pkw.gov.pl/pl/, 29.03.2015.

${ }^{7}$ W 2014 roku w trybie inicjatywy ludowej złożono wniosek, aby wymagana liczba podpisów została obniżona do 1500. Jak wskazano w uzasadnieniu, dotychczasowe brzmienie „Statutu Miasta Poznania nie zapewnia pełnej realizacji zasady bezpośredniego decydowania członków wspólnoty samorządowej o sprawach dotyczących tej wspólnoty, a tym samym realizacji zasady demokracji bezpośredniej [...]. Obniżenie wymogu uzyskania 5000 głosów poparcia przez wnioskodawcę do 1500 głosów spowoduje aktywizację mieszkańców w kwestii ich zainteresowania i troski o dobro wspólnoty samorządowej”; Obywatelski projekt zmiany uchwaty nr LXXX/1202/V/2010 Rady Miasta Poznania $z$ dnia 9 listopada 2010 roku w sprawie Statutu Miasta Poznania, http://prawodomiasta.org/wp-content/ uploads/2014/10/Wniosek-do-RMP-o-podjecie-uchwaly-ws-zmiany-statutu-1.pdf, 29.03.2015.

${ }^{8}$ Fundacja poddała analizie 619 statutów jednostek samorządu terytorialnego (badaniem objęto wszystkie powiaty i gminy miejskie); zob. szerzej: A. Widera, Statut rady: inicjatywa uchwałodawcza rzadko w rękach mieszkańców, http://www.portalsamorzadowy.pl/komunikacja-spoleczna/statut-radyinicjatywa-uchwalodawcza-rzadko-w-rekach-mieszkancow,68241_0.html, 29.03.2015. 
odnośnie możliwości ustanowienia w statucie jednostki samorządu terytorialnego przedmiotowej formy demokracji bezpośredniej. Przeprowadzona analiza pozwala sądzić, iż obywatelska inicjatywa uchwałodawcza mieści się w aktualnie obowiązującym porządku prawnym. Jednakże w celu wyeliminowania wszelkich wątpliwości wydaje się, iż najlepszym rozwiązaniem będzie ustanowienie podstawy prawnej dla omawianej formy partycypacji mieszkańców w funkcjonowaniu wspólnoty samorządowej na poziomie ustawowym. Wskazane rozwiązanie zostało zaproponowane w prezydenckim projekcie ustawy o współdziałaniu w samorządzie terytorialnym na rzecz rozwoju lokalnego i regionalnego. I choć w zakresie szczegółowych rozwiązań przewidzianych w przedmiotowej inicjatywie można wyrazić wątpliwości (np. odnośnie poparcia dla lokalnych inicjatyw ludowych), to jednak projekt zasługuje na pozytywną ocenę co do ogólnego kierunku zmian. Nie ulega wątpliwości, iż poszerzenie podstaw prawnych dla instytucji demokracji bezpośredniej może pomóc w budowie fundamentu współczesnej demokracji, tj. społeczeństwa obywatelskiego.

Przeprowadzona analiza rozwiązań przyjętych w statutach Łodzi i Poznania pozwala odnotować pewne różnice, które w szczególności odnoszą się do wysokości poparcia społecznego niezbędnego do skutecznego przedłożenia obywatelskiego projektu uchwały. W przypadku Poznania należy zebrać 5000 podpisów, natomiast w Łodzi 1000. Jednakże porównanie liczb bezwzględnych, które obowiązują w poszczególnych jednostkach samorządu terytorialnego nie jest najlepszą metodą analizy. Właściwsze będzie porównanie wymaganego poparcia w stosunku do ogółu mieszkańców mogących podpisać lokalną inicjatywę ludową. Biorąc pod uwagę przedmiotowe kryterium okazuje się, że w Poznaniu należy zebrać 7-krotnie więcej podpisów niż w Łodzi ${ }^{9}$. Wydaje się, iż rozwiązania przyjmowane w tym zakresie powinny być możliwe przychylne mieszkańcom, aby omawiana forma demokracji bezpośredniej była dostępna dla grup organizowanych doraźnie. Wymóg zebrania kilku (kilkunastu) tysięcy podpisów stanowi poważne przedsięwzięcie organizacyjne, co może zniechęcać mieszkańców do inicjowania procedury mającej na celu wystąpienie z obywatelskim projektem uchwały.

\section{Bibliografia}

Augustyniak M. (2014), Inicjatywa uchwałodawcza mieszkańców jako forma partycypacji społecznej w jednostkach samorzadu terytorialnego - wnioski de lege lata i postulaty de lege ferenda, w: Partycypacja społeczna w samorzqdzie terytorialnym, red. B. Dolnicki, Warszawa.

Banaszak B., Preisner A. (1996), Prawo konstytucyjne. Wprowadzenie, Wrocław.

Brzeski M. (2014), Problem podstawy prawnej regulacji obywatelskiej inicjatywy uchwałodawczej w statucie jednostki samorzadu terytorialnego, w: Partycypacja społeczna w samorzadzie terytorialnym, red. B. Dolnicki, Warszawa.

Druk nr 1699, Sejm RP VII kadencji.

Grabowska S. (2005), Instytucja ogólnokrajowej inicjatywy ludowej w wybranych państwach europejskich. Studium prawno-porównawcze, Rzeszów.

Izdebski H., Podstawy prawne wprowadzenia instytucji inicjatywy uchwałodawczej mieszkańców do statutów jednostek samorzqdu terytorialnego, http://www.maszglos.pl/wp-content/

${ }^{9} \mathrm{~W}$ Poznaniu musi się podpisać $1,2 \%$, natomiast w Łodzi $0,17 \%$ mieszkańców posiadających czynne prawo wyborcze. 
uploads/2013/04/Podstawy-prawne-wprowadzenia-instytucji-inicjatywy-uchwalodawczejmieszkancow-do-statutow-jednostek-samorzadu-terytorialnego-prof-Hubert-Izdebski.pdf, 21.03.2015.

Konstytucja Rzeczypospolitej Polskiej z dnia 2 kwietnia 1997 roku, Dz. U. Nr 78, poz. 483, z późn. $\mathrm{zm}$.

Krześnicki I., Inicjatywa obywatelska w sprawie podjęcia uchwaty przez organ stanowiacy j.s.t. nie może pozostać bez rozpatrzenia, http://www.samorzad.lex.pl/czytaj/-/artykul/inicjatywa-obywatelska-w-sprawie-podjecia-uchwaly-przez-organ-stanowiacy-j-s-t-nie-moze-pozostac-bezrozpatrzenia, 21.03.2015.

Kubel-Grabau A., Mieszkańcy tworzq uchwate, http://www.decydujmyrazem.pl/o_projekcie/wiadomosci/mieszkancy_tworza_uchwale.html, 22.03.2015.

Łabędź K. (2015), Partycypacja obywatelska na poziomie lokalnym - formy i ograniczenia, „Przegląd Politologiczny" nr 4.

Makowski G. (2012), Obywatelska inicjatywa uchwałodawcza - prawo i praktyka, w: Dyktat czy uczestnictwo? Diagnoza partycypacji publicznej w Polsce, t. I, red. A. Olech, Warszawa.

Makowski G. (2013), Ramy prawne partycypacji-stan obecny, zmiany, perspektywy, w: Partycypacja obywatelska-decyzje bliższe ludziom, red. A. Maszkowska, K. Sztop-Rutkowska, Białystok.

Makowski G., Czy prawo do inicjatywy uchwałodawczej mieszkańców może być wbrew prawu?, http:// www.isp.org.pl/decydujmyrazem/aktualnosci,1,443.html, 12.03.2015.

Miruć A. (2010), Obywatelska inicjatywa uchwałodawcza, „Samorząd Terytorialny”, nr 1-2.

Musiał-Karg M. (2014), Demokracja bezpośrednia w szwajcarskich kantonach. Wybrane uwagi na temat referendum, inicjatywy ludowej oraz zgromadzenia ludowego, „Społeczeństwo i Polityka”, $\operatorname{nr} 2$ (12).

Obrzut A. (2010), Inicjatywa uchwałodawcza mieszkańców, „Wspólnota”, nr 13.

Obywatelski projekt zmiany uchwaty nr LXXX/1202/V/2010 Rady Miasta Poznania z dnia 9 listopada 2010 roku w sprawie Statutu Miasta Poznania, http://prawodomiasta.org/wp-content/uploads/2014/10/Wniosek-do-RMP-o-podjecie-uchwaly-ws-zmiany-statutu-1.pdf, 29.03.2015.

Państwowa Komisja Wyborcza, Wybory samorzqdowe 2014, wybory2014.pkw.gov.pl/pl/, 29.03.2015.

Rachwał M. (2013), Budżet partycypacyjny jako nowa forma współdecydowania o finansach lokalnych, „Przegląd Politologiczny”, nr 4.

Szacka B. (2008), Wprowadzenie do socjologii, Warszawa.

Uchwała Nr LXVII/1301/09 Rady Miejskiej w Łodzi z dnia 4 listopada 2009 roku w sprawie ogłoszenia tekstu jednolitego Statutu Miasta Łodzi, Dz. Urz. Woj. Łódzkiego 2009, Nr 347, poz. 2860.

Uchwała Nr LXXX/1202/V/2010 Rady Miasta Poznania z dnia 9 listopada 2010 roku w sprawie Statutu Miasta Poznania, Dz. Urz. Woj. Wielkopolskiego 2011, Nr 11, poz. 303.

Uchwała Nr XCIII/1964/14 Rady Miejskiej w Łodzi z dnia 24 września 2014 roku w sprawie zmiany Statutu Miasta Łodzi, Dz. Urz. Woj. Łódzkiego 2014, poz. 3718.

Ustawa z dnia 14 czerwca 1960 roku Kodeks postepowania administracyjnego, t.j. Dz. U. 2016, poz. 23. Ustawa z dnia 15 września 2000 roku o referendum lokalnym, t.j. Dz. U. 2013, poz. 706, z późn. zm.

Ustawa z dnia 24 czerwca 1999 roku o wykonywaniu inicjatywy ustawodawczej przez obywateli, Dz. U. $\mathrm{Nr} 62$, poz. 688 , z późn. zm.

Ustawa z dnia 5 czerwca 1998 roku o samorzqdzie powiatowym, t.j. Dz. U. 2015, poz. 1445, z późn. zm.

Ustawa z dnia 5 czerwca 1998 roku o samorzqdzie województwa, t.j. Dz. U. 2015, poz. 1392, z późn. $z m$.

Ustawa z dnia 8 marca 1990 roku o samorzqdzie gminnym, t.j. Dz. U. 2015, poz. 1515, z późn. zm.

Uziębło P. (2000), Ustawa z 1999 roku o wykonywaniu inicjatywy ustawodawczej przez obywateli, „Przegląd Sejmowy”, nr 4. 
Widera A., Statut rady: inicjatywa uchwałodawcza rzadko w rękach mieszkańców, http://www.portalsamorzadowy.pl/komunikacja-spoleczna/statut-rady-inicjatywa-uchwalodawcza-rzadko-wrekach-mieszkancow,68241_0.html, 29.03.2015.

Wołodźko K., Lokalni bezradni, http://nowyobywatel.p1/2014/01/27/lokalni-bezradni, 28.03.2015.

Wyrok Naczelnego Sqdu Administracyjnego, sygn. II OSK 1887/13, orzeczenia.nsa.gov.p1/doc/ 469F3F3669, 7.03.2015.

Wyrok Naczelnego Sqdu Administracyjnego, sygn. OSK 1122/04, http://www.orzeczenia-nsa.pl/wyrok/ osk-1122-04/statut_rozstrzygniecia_nadzorcze_dotyczace_gminy_skargi_organow_na_czynnosci_samorzad_terytorialny $/ 1504 \mathrm{c} \overline{5} \mathrm{e} . \mathrm{html}, 21.03 .2015$.

Wyrok Wojewódzkiego Sadu Administracyjnego w Olsztynie, sygn. II SA/Ol 737/08, orzeczenia.nsa. gov.pl/doc/6910230A5D, 7.03.2015.

Wyrok Wojewódzkiego Sadu Administracyjnego we Wrocławiu, sygn. III SA/Wr 584/05, orzeczenia.nsa. gov.p1/doc/5D8E8D407B, 7.03.2015.

Zarządzenie Nr 224/2014/P Prezydenta Miasta Poznania z dnia 18 kwietnia 2014 roku w sprawie przeprowadzenia na terenie miasta Poznania konsultacji spolecznych $w$ sprawie budżetu Miasta Poznania na rok 2015, http://bip.poznan.pl/bip/zarzadzenia-prezydenta/224-2014p,NT001156EE/, 29.03.2015.

\section{Civic legislative initiative in Poland as seen by law - selected issues}

\section{Summary}

The civic legislative initiative can be defined as the right of the citizens of local communities to submit a draft of a law. This instrument of direct democracy is envisaged neither by the Constitution of Poland, nor by the laws that regulate the operations of municipalities, districts and provinces. The procedure of civic legislative initiative, however, is provided for in the statutes of local government units, which has resulted in negative assessments by some administrative courts. The analysis conducted here indicates that the civic legislative initiative is allowed within the framework of current legislation. This standpoint was expressed in the 2013 decision of the Supreme Administrative Court, among other things.

It seems that the best solution would be to provide for the civic legislative initiative in an act of law (as proposed in the presidential draft of a law on cooperation in local governments to facilitate local and regional development). Adopting this solution would eliminate any legal concerns on the one hand, and create an opportunity to make civic legislative initiatives more popular on the other. It should be borne in mind that active civic participation in political life is of the utmost significance for the proper functioning of a democratic state. Therefore, a de lege ferenda postulate can be brought forward to ensure that legal regulations allow citizens to implement civic legislative initiatives to the greatest extent possible.

Key words: local government direct democracy, people's initiative, civic legislative initiative 
